\title{
PENGGUNAAN KULIT UBI KAYU (Manihot utillisima Pohl) TERHADAP PENYERAPAN LOGAM Fe (III) PADA AIR PAYAU
}

\section{[Absorption of Fe (III) Metal in Brackish Water Using Cassava Peel (Manihot utillisima Pohl)]}

\author{
Delta Rinanda Duda ${ }^{\star}$, Syaiful Bahri ${ }^{1}$, Jaya Hardi ${ }^{1}$, Nov Irmawati Inda ${ }^{1}$ \\ 1) Jurusan Kimia, Fakultas MIPA, Universitas Tadulako, Palu \\ J. Soekarno Hatta Km.9, Kampus Bumi Tadulako Tondo Palu, Telp. 0451- 422611
}

*)Coresponding author: deltarinanda96@gmail.com(082396168049)

Diterima 13 Desember 2018, Disetujui 22 Mei 2019

\begin{abstract}
The absorption of Fe (III) metal in brackish water in the Balaroa Village, West Palu District using Cassava peels (Manihot utillisima Pohl) has been carried out. The aim of this study is determining the lifetime of cassava peels (Manihot utillisima Pohl) on the absorption of Fe (III) ions in brackish water. The research was conducted in a simple purification water system. Brackish water was flowed through the simple purification water system containing Cassava peels (Manihot utillisima Pohl) with a volume of brackish water is 10 liters per day (measured flow rate) and been analyzed every 2 days using UV-Vis spectrophotometry for less than 1 month. The results of the study show that cassava peel could be used as biosorbent to absorb and reduce level of Fe (III) ions in brackish water for 2.821 months. The concentration of Fe (III) ions in brackish water in Balaroa Village, West Palu District is $1.666 \mathrm{ppm}$.
\end{abstract}

Keywords : Fe (III) Ion, Biosorbent, Cassava Peel

\begin{abstract}
ABSTRAK
Kulit ubi kayu (Manihot utillisima Pohl) telah digunakan pada penjerapan logam Fe (III) dalam air payau di Kelurahan Balaroa Kecamatan Palu Barat. Tujuan dari penelitian ini untuk menentukan waktu penggunaan kulit ubi kayu dalam menjerap ion Fe (III) dalam air. Penentuan waktu penggunaan kulit ubi kayu dalam menjerap ion Fe (III) dilakukan dengan menggunakan perangkat sederhana alat penjernihan air dimana sampel air dialirkan dengan volume 10 liter per hari (diukur laju alirnya) dan dianalisis setiap 2 hari sekali menggunakan Spektrofotometri UV-Vis selama \pm 1 bulan. Hasil penelitian diperoleh bahwa kulit ubi kayu dapat digunakan sebagai biosorben untuk menyerap dan menurunkan kadar ion Fe (III) dalam air selama 2,821 bulan. Berdasarkan hasil analisis, konsentrasi ion Fe (III) yang terdapat dalam air sebagai objek penelitian yaitu 1,666 ppm.
\end{abstract}

Kata Kunci : Ion Fe, Biosorben, Kulit Ubi Kayu. 


\section{LATAR BELAKANG}

Air merupakan kebutuhan yang harus terpenuhi, dan sudah menjadi kebutuhan pokok yang perlu diperhatikan baik dari segi ketersediaan maupun kualitasnya. Air dengan kualitas yang baik sangat sulit didapat karena banyaknya pencemaran yang disebabkan oleh limbah rumah tangga, kegiatan industri dan lain sebagainya. Polutan yang umum dijumpai pada air yang berwarna keruh dan kekuningan adalah Fe dengan kadar yang cukup tinggi sehingga tidak bisa langsung dikonsumsi. Masalah tersebut dapat diatasi dengan melakukan pengolahan air untuk mengurangi kadar $\mathrm{Fe}$ yang terkandung didalammya (Wardhana, 2004).

Syarat air minum dan air bersih telah ditetapkan dalam peraturan Menteri Kesehatan Republik Indonesia Nomor 416/MenKes/PER/IX/1990. Di kota Palu, sumber air minum yang digunakan masih banyak yang tidak memenuhi standar yang ditentukan. Salah satunya adalah bersifat payau dan tidak layak dijadikan air minum. Air payau umumnya tidak memenuhi persyaratan air minum yang sudah distandarkan karena air payau memiliki ciri warna kuning dengan kandungan Fe 5 mg/L, sehingga kadar Fe yang cukup tinggi ini menyebabkan kualitas air menurun. Kadar Fe dalam air minum yang diperbolehkan adalah $<0,3$ $\mathrm{mg} / \mathrm{L}$. Adanya kadar Fe yang tinggi akan menyebabkan pakaian mudah rusak dan menyebabkan gangguan kesehatan bagi yang mengonsumsinya dalam jangka lama dan dengan jumlah yang banyak. Upaya reduksi logam $\mathrm{Fe}$ dalam air dilakukan dengan metode adsorbsi menggunkan adorben ataupun biosorben. Salah satu biosorben yang petensial adalah kulit ubi kayu. Potensi ubi kayu di Sulawesi Tengah sangat tinggi, yaitu 47.295 ton umbi basah berkulit pada tahun 2015 (BPS Provinsi Sulawesi Tengah, 2012). Menurut Suhendrayatna (2001), ubi kayu memiliki kandungan selulosa sebanyak 43,626 \% sehingga dengan adanya kandungan selulosa itu maka ubi kayu berpotensi untuk digunakan sebagai biosorben. Gugus aktif $-\mathrm{OH}$ dalam selulosa dapat menyerap berbagai jenis logam.

Kemampuan biosorben untuk menyerap logam berat tergantung dari sumber biosorben, waktu penyerapan dan rasio biosorben terhadap jumlah konsentrasi larutan logam berat. Laroni (2014) memanfaatkan kulit ubi kayu sebagai biosorben logam $\mathrm{Fe}$ dan menyatakan bahwa kemampuan biosorben untuk menyerap logam berat tergantung dari waktu penyerapan dan rasio biosorben terhadap jumlah konsentrasi larutan logam berat Fe.

Tepare et al. (2018) telah melakukan penelitian mengenai pengolahan air minum menggunakan kulit ubi kayu dengan perlakuan variasi tinggi adsorben dan laju alir. Hasil penelitian tersebut didapatkan bahwa semakin tinggi adsorben dan semakin rendah laju alir, 
maka proses penyerapan ion Fe semakin baik. Penyerapan ion Fe terbaik dengan persentase penyerapan sebesar $74,82 \%$, yaitu pada penggunaan adsorben dengan tinggi $40 \mathrm{~cm}$ dan laju alir $25 \mathrm{ml} /$ menit. Rohani et al. (2014) melaorkan bahwa kulit ubi kayu/ singkong memiliki daya serap tertinggi pada logam Fe hingga 92\% dibandingkan dengan kulit ubi dan pisang.

Salah satu faktor yang perlu dikaji adalah efektivitas penggunaan atau ketahanan biosorben untuk menjerap ion logam Fe. Belum adanya kajian efektivitas penggunaan biosorben kulit ubi kayu, maka diperlukan penelitian mendalam ke arah tersebut, sehingga dapat menjadi gambaran pada saat diaplikasikan di masyarakat.

\section{METODE PENELITIAN}

\section{Bahan dan Peralatan}

Bahan dasar yang digunakan dalam penelitian ini adalah kulit ubi kayu, air sumur warga RW 9 kelurahan balaroa, aluminium foil, natrium hipoklorit, kertas saring, feri ammonium sulfat $\left(\mathrm{NH}_{4} \mathrm{Fe}\left(\mathrm{SO}_{4}\right)_{2}\right), \mathrm{HCl}$, potassium tiosianat (KSCN) dan aquadest.

Peralatan yang digunakan berupa blender, ayakan 20 mesh, rangkaian alat penyaringan (Gambar 1), neraca analitik, pektrofotometri UV-Vis Perkinelmer.

\section{Prosedur Penelitian}

\section{Preparasi Sampel Kulit Ubi Kayu (Metode Bahri dkk, 2017)}

Kulit ubi kayu yang sudah dipisahkan dari kulit luarnya dicuci dengan air bersih. Setelah itu direndam dengan air hangat \pm 5 menit. Dijemur dibawah terik matahari hingga kering \pm 5 hari, kemudian dihancurkan lalu diayak dengan ayakan 20 mesh. Kulit ubi kayu selanjutnya dicuci dan direndam dengan natrium hipoklorit $2 \%$ yang diulangi selama $3 \times 24$ jam, kemudian dicuci dan direndam dengan air selama 1 malam. Kulit ubi kayu selanjutnya dikeringkan dan siap digunakan sebagai biosorben.

\section{Penjernihan Air dengan Biosorben Kulit Ubi Kayu (Modifikasi Metode Bahri dkk, 2017)}

Pada alat penjernihan yang sudah dirangkai (Gambar 1), dimasukkan sampel ke dalam wadah air. Sampel selanjutnya dialirkan melalui pipa berdiameter $1 \frac{1}{4}$ inchi dan telah diisi biosorben sepanjang $80 \mathrm{~cm}$. Hasil dari sampel yang dialirkan melalui pipa rangkaian ditampung dan di ukur laju alirnya (mL/menit), kemudian diamati penampakan fisik dari air hasil penjernihan.

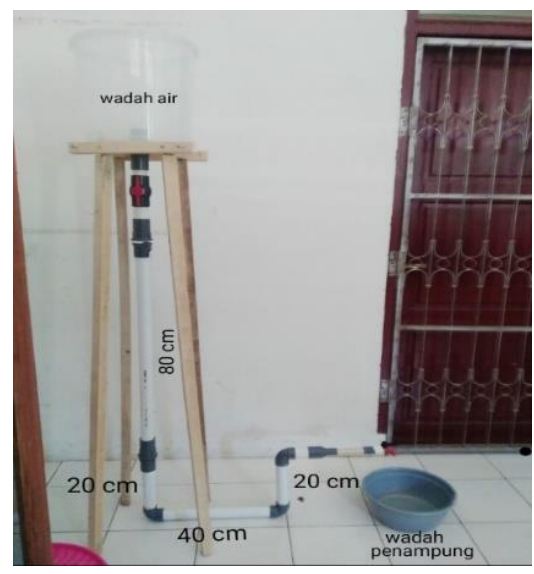

Gambar 1 Rangkaian Alat Penjernihan Air

Hasil penjernihan selanjutnya dianalisis kandungan Fe menggunakan 
spektrofotometri UV-Vis pada panjang gelombang $480 \mathrm{~nm}$. Analisis ini dilakukan setiap 2 hari sekali selama \pm 1 bulan dengan volume sampel air yang dialirkan tiap harinya yaitu $10 \mathrm{~L}$.

\section{Penentuan panjang gelombang maksimum}

0,3 ml larutan standar Fe dalam labu ukur $50 \mathrm{ml}$ ditambahkan $5 \mathrm{ml}$ larutan tiosianat dan $3 \mathrm{ml} \mathrm{HCl} 4 \mathrm{~N}$.Ukur serapan dari larutan itu pada panjang gelombang antara 375-525 nm. Buat kurva serapan Vs panjang gelombang dan tentukan panjang gelombang maksimumnya.

\section{Pembuatan kurva kalibrasi}

Dalam 5 labu ukur $50 \mathrm{ml}$, dimasukkan larutan standar besi sebanyak 0,25 ml; 0,5 ml; 0,75 ml; $1 \mathrm{ml}$ dan $1,25 \mathrm{ml}$ sehingga didapat konsentrasi 0,$5 ; 1 ; 1,5 ; 2$ dan 2,5 ppm. Selanjutnya tambahkan $5 \mathrm{ml} \mathrm{KCNS}$ dan $3 \mathrm{ml} \mathrm{HCl} 4 \mathrm{~N}$ dan diimpitkan dengan aquadest hingga tanda batas. Kemudian diukur serapannya dan dibuat kurva kalibrasinya.

\section{Penentuan kadar besi dalam larutan}

Diambil $0,25 \mathrm{ml}$ larutan sampel dalam labu $50 \mathrm{ml}$ dan ditambahkan $5 \mathrm{ml}$ KCNS $2 \mathrm{M}, 3 \mathrm{ml} \mathrm{HCl} 4 \mathrm{~N}$ dan diimpitkan dengan aquadest. Selanjutnya diukur serapannya pada panjang gelombang 480 $\mathrm{nm}$. Kemudian ditentukan kadar besi dalam larutan.

\section{Analisa Data}

Jumlah Fe yang teradsorpsi $(\mathrm{mg} / \mathrm{g}$ ) ditentukan berdasarkan banyaknya zat terlarut yang teradsorpsi oleh setiap gram adsorben. Perhitungan jumlah $\mathrm{Fe}$ yang teradsorpsi $(\mathrm{mg} / \mathrm{g})$ ditentukan dengan rumus :

$$
A=\frac{C_{1}-C_{2} \times V}{m}
$$

Dimana A adalah jumlah $\mathrm{Fe}$ yang teradsorpsi oleh biosorben kulit ubi kayu $(\mathrm{mg} / \mathrm{g}), \mathrm{C}_{1}$ adalah konsentrasi $\mathrm{Fe}$ awal (ppm), $\mathrm{V}$ adalah volume $\mathrm{Fe}$ yang digunakan $(\mathrm{mL})$ dan $\mathrm{m}$ adalah berat biosorben yang digunakan (gram) (Sianipar et al, 2016).

\section{HASIL DAN PEMBAHASAN}

\section{Waktu Penggunaan Biosorben dalam Menyerap Ion Fe}

Pada proses adsorpsi yang telah dilakukan untuk mengetahui waktu penggunaan kulit ubi kayu dalam menyerap ion Fe (III) pada air, didapatkan variasi hari analisis yang berpengaruh pada penyerapan ion $\mathrm{Fe}$ (III). Hasil analisis menggunakan spektrofotometer UV-Vis, konsentrasi ion Fe yang terdapat dalam air payau sebagai objek penelitian yaitu sebesar 1,666 ppm.

Penyerapan ion Fe (III) pada air payau terus meningkat sampai $97,779 \%$ pada hari ke-21 penggunaan biosorben kulit ubi kayu, namun pada hari ke-24 sampai pada hari ke-27 penyerapannya justru menurun menjadi $82,292 \%$ dan $77,310 \%$ (Gambar 2). Hal ini disebabkan karena terjadinya proses desorpsi. Menurut Antonia (2014), desorpsi merupakan proses pelepasan kembali ion atau molekul yang telah berikatan dengan gugus aktif pada adsorben. Desorpsi 
terjadi karena konsentrasi Fe yang terserap pada permukaan kulit ubi kayu sudah lebih besar dibandingkan dengan konsentrasi Fe (III) yang ada dalam sampel air sebelum penjernihan. Perbedaan konsentrasi tersebut menyebabkan ion $\mathrm{Fe}$ (III) yang sudah terikat pada biosorben kulit ubi kayu akan terdesorpsi kembali ke dalam sampel air tadi sehingga efektivitas penyerapan ion $\mathrm{Fe}$ (III) menjadi menurun dan bertambahnya jumlah ion $\mathrm{Fe}$ (III) dalam sampel air setelah penjernihan.

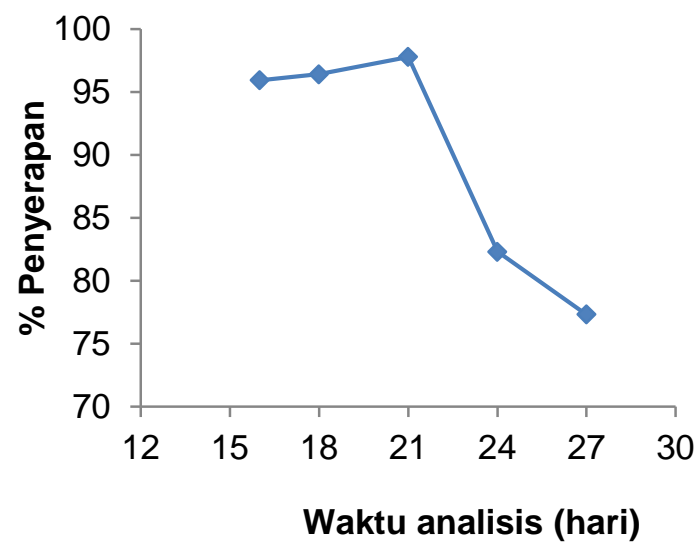

Gambar 2 Penyerapan ion Fe (III) air payau pada penggunaan hingga 27 hari.

Menurut Antonia (2014) efisiensi adsorpsi besi yang baik, yaitu 29,2 \%, sehingga berdasarkan perhitungan, didapatkan bahwa kulit ubi kayu dapat digunakan sebagai biosorben untuk menyerap ion $\mathrm{Fe}$ (III) dalam air selama 2,8 bulan.

\section{Pengaruh Laju Alir Terhadap Daya Serap Ion Fe}

Penggunaan laju alir $27 \mathrm{ml} / \mathrm{menit}$ menghasilkan penyerapan ion $\mathrm{Fe}$ (III) hingga 88,955 \% pada penggunaan biosorben hari ke 2 sampai hari ke 6 (Gambar 3). Pada hari ke 8-12 dengan laju alir $22 \mathrm{ml} /$ menit penyerapan meningkat menjadi $94,117 \%$. Pada laju alir $15 \mathrm{ml} /$ menit (penggunaan hari ke 1418) penyerapan meningkat sampai 95,918\%. Tetapi pada penggunaan ke 21 sampai 27 hari dengan laju alir $9 \mathrm{ml} /$ menit, penyerapan ion $\mathrm{Fe}(\mathrm{III})$ menurun sampai $85.774 \%$.

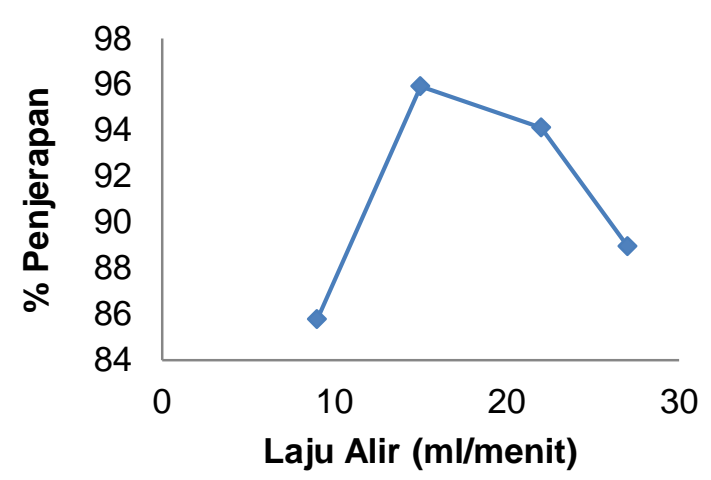

Gambar 3 Penyerapan ion Fe (III) air payau pada laju alir yang beragam.

Hasil penelitian ini berbeda dengan penelitian yang dilakukan oleh Tepare et al. (2018) bahwa semakin lambat laju alir, maka proses penyerapan akan semakin baik karena semakin lambat laju alir, maka interaksi antara ion $\mathrm{Fe}$ (III) dengan biosorben kulit ubi kayu menjadi semakiin lama sehingga proses penyerapan pun akan semakin tinggi. Ketidaksesuaian ini dikarenakan adanya faktor penggunaan biosorben yang terus-menerus digunakan secara kontinyu sehingga daya serap ion $\mathrm{Fe}$ (III) menjadi berkurang walaupun laju alirnya kecil.

Penelitian yang juga menggunakan kulit ubi kayu sebagai biosorben juga telah 
dilakukan oleh Tepare et al. (2018) menggunakan metode kolom dengan penyerapan ion $\mathrm{Fe}$ terbaik yaitu pada tinggi adsorben $40 \mathrm{~cm}$ dan laju alir 25 $\mathrm{ml} /$ menit dengan persentase penyerapan sebesar 74,82 \%. Dari hasil tersebut, diasumsikan bahwa semakin tinggi kolom adsorben, maka semakin banyak biosorben yang digunakan sehingga semakin besar potensi biosorben untuk menyerap ion Fe (III) yang terdapat pada air.

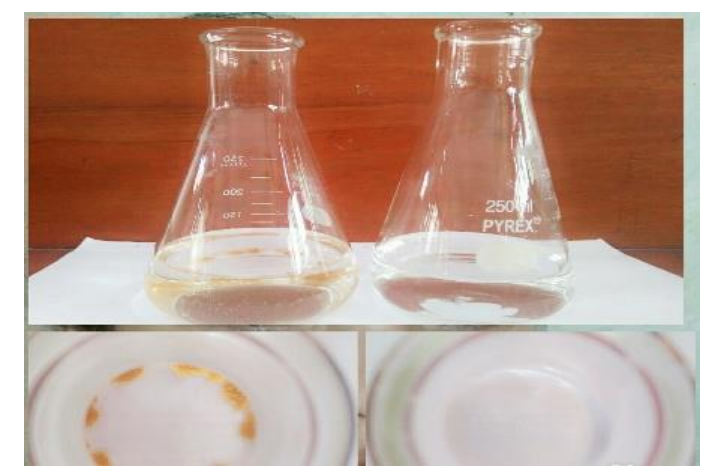

Gambar 4 Perbandingan sir sebelum dan sesudah penjernihan

Perubahan warna pada air sebelum dan sesudah perlakuan sangat jelas (Gambar 4). Sebelum perlakuan, warna air keruh dan terdapat endapan kekuningan, sedangkan setelah perlakuan, warna air berubah menjadi bening dan tidak terdapat lagi endapan. Hasil analisis menggunakan Spektrofotometer UV-Vis, konsentrasi ion Fe yang terdapat dalam air sebelum perlakuan yaitu 1,666 ppm dan setelah perlakuan, konsentrasi ion Fe menurun dengan penurunan terbaik yaitu menjadi 0,037 ppm.
Pada proses adsorpsi ini melibatkan reaksi kimia antara selulosa dan ion logam Fe yang terdapat dalam air. Selulosa mempunyai kemampuan untuk mengadsorpsi logam berat secara kimia. Hal ini dikarenakan selulosa memiliki gugus hidroksil yang dapat berinteraksi dengan logam berat. Menurut Nurhayati dan Sutrisno (2013), bahan-bahan yang mempunyai gugus hidroksil $(-\mathrm{OH})$ dapat dipakai untuk mengadsorpsi ion-ion logam berat.

$-\mathrm{Y}-\mathrm{OH}+\mathrm{M}^{+} \rightleftarrows-\mathrm{YO}-\mathrm{M}+\mathrm{H}^{+}$
Mekanisme tersebut merupakan mekanisme pertukaran ion, dimana $\mathrm{M}^{+}$ adalah ion logam, $-\mathrm{OH}$ adalah gugus hidroksil dan $\mathrm{Y}$ adalah matriks tempat gugus $-\mathrm{OH}$ terikat. Interaksi antara gugus - $\mathrm{OH}$ dengan ion $\mathrm{Fe}$ yaitu pada gugus $\mathrm{OH}$ mempunyai pasangan electron bebas, sedangkan ion Fe mempunyai orbital $s$ kosong. Pasangan electron bebas tersebut akan menempati orbital kosong yang dimiliki oleh ion $\mathrm{Fe}$ sehingga terbentuk suatu senyawa (Nurhayati dan Sutrisno, 2013).

\section{KESIMPULAN}

Kulit ubi kayu dapat digunakan sebagai biosorben untuk menyerap ion $\mathrm{Fe}$ (III) dalam air di Kelurahan Balaroa Kecamatan Palu Barat selama 2,8 bulan. Laju alir berpengaruh pada penjerapan ion Fe (III) dimana semakin rendah laju alir maka penjerapan akan semakin baik namun semakin lama waktu penggunaan 
biosorben maka penyerapan akan menurun walaupun laju alirnya rendah.

\section{DAFTAR PUSTAKA}

Antonia N., dan Adhitiyawarman. 2014. Pemanfaatan Tongkol Jagung Sebagai Adsorben Besi Pada Air Tanah. JKK 3(3):7-13.

Bahri, S., Musafira, Hardi, J., Satrimafitrah, P. 2017. Pemanfaatan Kulit Ubi Kayu Sebagai Biosorben Pada Penjernihan Air di Kelurahan Balaroa. KOVALEN, 3(2):196-200.

Rohani D,A. Juswono U P., Nuriyah L. 2014. Pengukuran Efektivitas Kulit Singkong, Kulit Ubi Jalar, Kulit Pisang Dan Kulit Jeruk Sebagai Bahan Penyerap Besi (Fe) Dan Mangan (Mn) Pada Air Lindi TPA. Brawijaya Physics Student Journal, 2(1).

Laroni, J. I. 2014. Pemanfaatan Kulit Ubi Kayu (Manihot Utillissima Pohl) Sebagai Biosorben Logam Fe. Skripsi. Palu: Jurusan Kimia FMIPA UNTAD.

Nurhayati I, Sutrisno J. 2013. Limbah Ampas Tebu Sebagai Penyerap Logam Berat Pb. Prosiding Seminar Nasional Universitas PGRI Adi Buana Surabaya. Hal : 59-70.

Sianipar, L D., Zaharah, T A., Syahbanu, I. 2016. Adsorpsi Fe(II) Dengan Arang Kulit Buah Kakao (Theobroma cacao L.) Teraktivasi Asam Klorida. JKK 5(2): 50-59.

Suhendrayatna. 2001. Heavy Metal Bioremoval by Microorganisme: A Literature Study. Institute for Technology Studies-Chapter Japan.

Tepare, E., Bahri, S., Musafira. 2018. Aplikasi Biosorben Kulit Ubi Kayu (Manihot utillisima Pohl) dalam Penyerapan Ion Fe (III) Pada Air Payau. KOVALEN, 4(3): 271-275.
Wardhana, W. 2004. Dampak Pencemaran Lingkungan.
Yogjakarta: ANDI.

